\title{
Evaluating the Parallel Classes on Inorganic Chemistry Undergraduates
}

\author{
Daud K. Walanda \\ Department of Mathematics and Science Education \\ Universitas Tadulako \\ Palu, Indonesia \\ walanda@gmail.com
}

\author{
Mery Napitupulu \\ Department of Mathematics and Science Education \\ Universitas Tadulako \\ Palu, Indonesia \\ merytn@gmail.com
}

\begin{abstract}
Parallel classes has been applied as an instructional approach to support students academic in undergraduate education classrooms including in science subjects. The purpose of this study was to identify the potentials and constraints of the implementation of parallel classes on undergraduate students of faculty of education, Tadulako University, Indonesia during the period of the academic year 2014--2016, in which inorganic subjects were taught in three classrooms denotes as A, B and C. All data were collected from records of score lists (DPNA) that included mid-test, final test, and laboratory grades. Significant differences in student' academic achievements and laboratory performances were found in these classes. Students in class $\mathbf{C}$ reported academically better than other classes either in lectures and in the laboratory. Student preferred small class and was taught by different lecturers. Based on these preliminary results, the parallel class which is practiced at the present has drawbacks for meeting the needs of students in inorganic chemistry classrooms.
\end{abstract}

Keywords-parallel classes; inorganic chemistry; learning outcomes; student perception, undergraduates

\section{INTRODUCTION}

In recent times, it is well known that instruction-learning and teaching, in higher education, especially in science such as chemistry subject, has become more challenging and more complicated for a number of reasons. These include a method of teaching which involving macro-, micro- and symbolic level of learning [1]-[5], students' understanding that aims increasing student expectations from teaching and learning [6]-[8] and academics' professional development [9]. Also, aspects such as a number of student in a classroom [10]-[11] become an issue as it can create a situation that can occasionally be inefficient and unrewarding for both students and academic staffs. A general opinion among academic faculty is that classes with enrollments of more than 100 students are not conducive to student participation which in turn affects their academic achievement [12]. This fact can in turn that higher education institutions inevitably require common strategies in order to manage the quality and equity of learning process.

During the past couple years, in almost all Indonesian higher education institutions in particularly the faculty of education the number of enrolled students is in increasing approximately $7.83 \%$ [13]. Therefore, an alternative strategy to resolve this hindrance is to accomplish parallel classes which have been practiced by chemistry education faculty of education (FKIP) Universitas Tadulako in which the incoming students of this study program are distributed into at least three classes in which, each class is taught by team teaching with the same syllabi. Chemistry is one of the important fields of science subjects offered to the chemistry education study program to equip the pre-service teacher to become a science educator. The field of chemistry is basically classified into five main divisions with the other types of chemistry typically falling into one of these branches: organic chemistry, inorganic chemistry, analytical chemistry, physical chemistry, and biochemistry. Since chemistry topics are generally related to or based on the structure of matter, chemistry proves a difficult subject for many students [14]. Inorganic chemistry is the descriptive study of the synthesis, reactions, structures, and properties of compounds of the elements which deals with non-metal elements, metal elements, physical inorganic chemistry, organometallic and bioinorganic chemistry divisions.

Studies on parallel classes towards student achievement have been performed by a number of group research such as [15]-[17] however, the subject mainly on mathematics and in the secondary schools. In addition, Jackson and Smith [16] study focused on students who attended single-sex education (SSE). Luyten and de Jong [17] revealed that the most important findings of their study were that student achievement may be very similar in classes taught by different teachers. This term of student distribution into a number of classes is in contrast with the so-called co-teaching [18]-[20]. Bacharach and Cloud [21] defined that co-teaching is defined as two academic staffs working together with groups of students; sharing the planning, organization, delivery, and assessment of instruction, in a single physical space.

This study primarily aims to identify the potentials and constraints of the implementation of parallel classes on undergraduate students of faculty of education in particular on inorganic chemistry courses. In addition, this study presents descriptive results of student preferences regarding parallel classes. 


\section{METHODS}

This study was conducted using a quantitative method. All inorganic chemistry grade data from classes A, B and C were gathered from records of score lists (designated as DPNA) supplied by faculty administration from the year 2014 to 2016. These data were mid-semester exam denoted as UTS, final semester denoted as UAS, laboratory (LAB) grade and a total of those grades. The last grade is assessed in comprising of the students' assignments. The inorganic chemistry II course which dealing with metal elements is offered for second-year undergraduate student and is usually scheduled in an even semester while physical inorganic chemistry is taught in the third year and is usually scheduled in the odd semester. Student preferences regarding parallel classes were collected from the undergraduate student $(n=60)$ in which $75 \%$ of the student were girls $(n=45)$ of Chemistry Education Program Study FKIP Universitas Tadulako through survey and prior to that, the students are told that all of their responses would be confidential. The mean age of the students was $19.40(S D=$ 0.72 ) and ages ranged from 18 to 21 . The questionnaire consists of six questions which were prepared using Google Forms and is uploaded to an Inorganic Chemistry blog maintained by the researcher. In another word, the questionnaire was administered to the students, not in regular class sessions. The data were analyzed using MS Excel.

\section{RESULTS AND DISCUSSION}

The findings of the study were reported in two groups: (i) findings obtained from analysis of student academic achievement through their grades in both inorganic chemistry II and physical inorganic chemistry courses that implement parallel classroom of A, B and C from year 2014 up to 2016; and (ii) findings of questionnaire analysis which focuses on gaining students' preferences regarding parallel class.

TABLE I. CLASSROOM STATISTICAL DATA OF EXAM TYPE FOR INORGANIC CHEMISTRY II COURSE PERIOD 2014-2016.

\begin{tabular}{|cc|ccccccccc|}
\hline \multirow{2}{*}{$\begin{array}{c}\text { Academic } \\
\text { Year }\end{array}$} & Grade & \multicolumn{7}{|c|}{ A } & \multicolumn{7}{|c|}{ Classroom } \\
\cline { 3 - 11 } & & Max & $M$ & $S D$ & Max & $M$ & $S D$ & Max & $M$ & $S D$ \\
\hline \multirow{3}{*}{2016} & UTS & 68.0 & 41.8 & 11.6 & 59.0 & 30.5 & 10.2 & 67.0 & 53.5 & 8.8 \\
& UAS & 90.0 & 73.0 & 14.1 & 96.2 & 73.9 & 17.9 & 95.0 & 91.7 & 2.9 \\
& LAB & 86.2 & 77.6 & 12.5 & 87.1 & 79.6 & 14.9 & 89.0 & 87.0 & 0.9 \\
& Total & 75.0 & 60.0 & 9.5 & 80.3 & 59.4 & 13.0 & 88.3 & 72.8 & 19.2 \\
\hline \multirow{3}{*}{2015} & UTS & 54.0 & 37.4 & 9.8 & 62.0 & 29.1 & 13.5 & 86.0 & 44.6 & 15.0 \\
& UAS & 96.1 & 74.3 & 15.0 & 81.1 & 64.0 & 9.1 & 85.0 & 80.1 & 0.7 \\
& LAB & 88.0 & 74.1 & 24.9 & 86.0 & 73.1 & 22.2 & 94.0 & 84.8 & 13.2 \\
& Total & 80.1 & 68.1 & 10.8 & 77.1 & 61.4 & 12.9 & 82.2 & 67.7 & 8.2 \\
\hline \multirow{3}{*}{2014} & UTS & 68.0 & 36.7 & 12.8 & 74.0 & 39.3 & 16.8 & 62.0 & 42.5 & 9.9 \\
& UAS & 90.0 & 71.2 & 16.0 & 90.0 & 56.7 & 15.6 & 86.0 & 63.7 & 11.9 \\
& LAB & 82.5 & 61.7 & 21.4 & 81.1 & 69.9 & 12.7 & 79.8 & 65.8 & 17.5 \\
& Total & 80.2 & 60.1 & 11.6 & 82.7 & 59.7 & 11.1 & 73.5 & 61.2 & 7.6 \\
\hline
\end{tabular}

TABLE II. CLASSROOM STATISTICAL DATA OF EXAM TYPE FOR PHYSICAL INORGANIC CHEMISTRY COURSE PERIOD 2014-2016

\begin{tabular}{|cc|cccccccccc|}
\hline \multirow{2}{*}{$\begin{array}{c}\text { Academic } \\
\text { Year }\end{array}$} & \multirow{8}{*}{ Grade } & \multicolumn{10}{|c|}{ Classroom } \\
\cline { 3 - 12 } & & A & \multicolumn{10}{|c|}{ B } & $M$ & $S D$ & Max & $M$ & $S D$ & Max & $M$ & $S D$ \\
\hline \multirow{3}{*}{2016} & UTS & 75.00 & 37.30 & 10.32 & 54.00 & 33.93 & 11.07 & 80.00 & 49.40 & 16.77 \\
& UAS & 90.00 & 65.38 & 11.90 & 95.50 & 49.51 & 17.23 & 98.00 & 48.88 & 25.18 \\
& LAB & 88.00 & 78.82 & 9.29 & 86.00 & 75.32 & 9.80 & 88.00 & 77.69 & 12.28 \\
& Total & 73.18 & 61.13 & 6.16 & 78.25 & 51.82 & 12.49 & 84.18 & 57.80 & 15.67 \\
\hline \multirow{3}{*}{2015} & UTS & 92.00 & 67.25 & 12.50 & 82.00 & 66.12 & 7.36 & 79.00 & 64.51 & 9.28 \\
& UAS & 90.00 & 55.47 & 14.49 & 78.00 & 52.75 & 12.08 & 90.00 & 65.00 & 17.73 \\
& LAB & 89.13 & 75.19 & 9.35 & 76.72 & 70.46 & 8.15 & 85.50 & 71.33 & 5.68 \\
& TOTAL & 85.00 & 66.88 & 8.26 & 76.74 & 63.54 & 7.51 & 81.28 & 68.99 & 7.53 \\
\hline \multirow{3}{*}{2014} & UTS & 72.00 & 39.21 & 19.16 & 72.00 & 35.76 & 13.83 & 42.00 & 33.33 & 6.75 \\
& UAS & 85.00 & 77.89 & 4.60 & 80.00 & 43.16 & 18.50 & 55.00 & 29.67 & 11.41 \\
& LAB & 82.59 & 62.24 & 8.48 & 73.36 & 58.03 & 16.30 & 71.34 & 67.02 & 3.46 \\
& Total & 80.72 & 62.68 & 8.46 & 67.00 & 46.79 & 20.39 & 55.01 & 44.70 & 5.69 \\
\hline
\end{tabular}


According to data given in Tables I and II, the student performance in term of their academic achievement during the period academic year 2014 up to 2016 showed significant differences. An example picture is shown in Fig. 1 and 2 of the total score of three classes for both courses. The student grade in class $\mathrm{C}$ for inorganic chemistry II was a bit higher than the other classes (Fig. 1). One possible explanation, the class $\mathrm{C}$ was a small class compared to classes A and B. This is in accordance with the questionnaire question regarding the number of student in the parallel classroom.

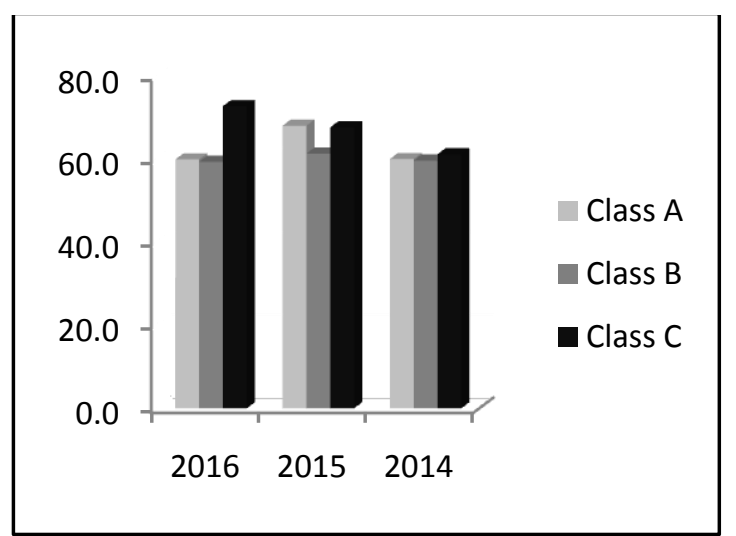

Fig. 1. Comparison of the mean of total grade between classes for inorganic chemistry II course.

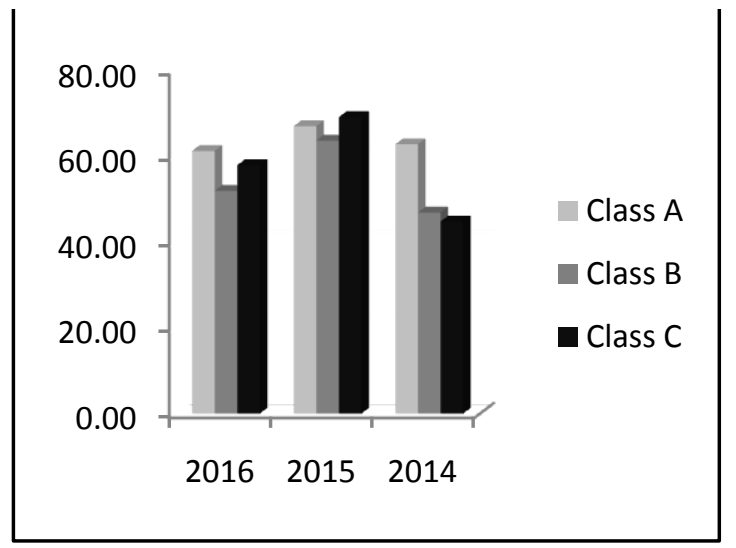

Fig. 2. Comparison of the mean of total grade between classes for a physical inorganic chemistry course.

Based on the questionnaire response, student prefers to choose their own class $(45 \%)$ in parallel class rather than administered by Coordinator Study Program $(41.7 \%)$. This is probably in connection with the term peer or mate that was built since the high school. Zimmerman [22] and Kang [23] have supported research regarding peer effect in the classrooms. The response to a question concerning the number of student in the parallel class, the student more likely to opt 30 students in maximum which counted $90 \%$, while the rest wish 40 student maximum in the class. Surprisingly, $70 \%$ of the student prefers that they were taught by a different lecturer in each class, and $21.7 \%$ of a student more likely to be taught by one lecturer in all three classes like in the theater. The method of teaching implemented by academic staffs in inorganic chemistry courses is a presentation by the lecturer which is more preferred by the student $(65 \%)$ compared to discussion method performing by a group of student $(28.3 \%)$. In this research, the student was also asked their preference regarding the evaluation process that is practiced by academic staffs and multiple choice test form was preferred by students $(91.6 \%)$ compared to an essay test form.

\section{CONCLUSIONS}

In this study, when the results are analyzed, it is seen that students of class $\mathrm{C}$ are more successful in their academic achievement both in lectures and in the laboratory, excluding on physical inorganic chemistry in the year 2014. With regards to distribution of student in parallel classes, student's preferred to select their classroom rather administered by program study and was taught by different lecturers in each classroom.

\section{ACKNOWLEDGMENTS}

The author would like to thank the faculty administration staffs for gathering student's grade data and also to all chemistry education students who participated in the survey which uploaded on the blog for this study.

\section{REFERENCES}

[1] A. H. Johnstone, "Why is science difficult to learn? Things are seldom what they seem," J. Comput. Assist. Learn., vol. 7, no. 2, pp. 75-83, 1991.

[2] Y. J. Y. Dori and M. Hameiri, "Multidimensional analysis system for quantitative chemistry problems: Symbol, macro, micro, and process aspects," J. Res. Sci. Teach., vol. 40, no. 3, pp. 278-302, 2003.

[3] V. Talanquer, "Macro, submicro, and symbolic: The many faces of the chemistry "triplet,", Int. J. Sci. Educ., vol. 33, no. 2, pp. 179-195, 2011.

[4] L. Z. Jaber and S. BouJaoude, "A macro-microsymbolic teaching to promote relational understanding of chemical reactions," Int. J. Sci., vol. 34, no. 7, pp. $973-$ 998, 2012.

[5] Z. Effandi and I. Zanaton, "Promoting cooperative learning in science and mathematics education: A Malaysian perspective," Eurasia J. Math. Sci. Technol. Educ., vol. 3, no. 1, pp. 35-39, 2009.

[6] C. A. Cloonan, C. A. Nichol, and J. S. Hutchinson, "Understanding chemical reaction kinetics and equilibrium with interlocking building blocks," J. Chem. Educ., vol. 88, pp. 1400-1403, 2011.

[7] S. Lee, "Exploring Students' Understanding Concerning Batteries-Theories and Practices," Int. J. Sci. Educ., vol. 29, no. 4, pp. 497-516, Mar. 2007.

[8] A. Hakim and A. Kadarohman, "Student Concept Understanding of Natural Products Chemistry in Primary and Secondary Metabolites Using the Data Collecting Technique of Modified CRI," Int. Online J. Educ. Sci., vol. 4, no. 3, pp. 544-553, 2012.

[9] C. Grace, D. Bordelon, P. Cooper, R. Kazelskis, C. Reeves, and D. G. Thames, "Impact of professional development on the literacy environments of preschool classrooms," J. Res. Child. Educ., vol. 23, no. 1, pp. 52$81,2008$.

[10] F. Shamim, N. Negash, C. Chuku, and N. Demewoz, Maximizing learning in large classes: Issues and options. Addis Ababa: British Council, 2007.

[11] S. Renaud, E. Tannenbaum, and P. Stantial, "Studentcentered teaching in large classes with limited resources," English Teach. Forum, vol. 3, pp. 12-34, 2007.

[12] L. Burnett, K. Krause, M. Barker, P. Woods, and R. Hibbins, Strategies for teaching large classes. 
Washington DC: Academy Administration Practice, 2010.

[13] M. Napitupulu and I. Makhmud, "Student admission system in state universities in Indonesia," ASAIHL2016, Kuala Lumpur, 2016.

[14] M. Niaz, "Facilitating conceptual change in students' understanding of electrochemistry," Int. J. Sci. Educ., vol. 24, no. 4, pp. 425-439, Apr. 2002.

[15] R. J. Bosker and J. Scheerens, "Issues in the interpretation of the results of school effectiveness research," Int. J. Educ. Res., vol. 13, no. 7, pp. 741-751, Jan. 1989.

[16] C. Jackson and I. Smith, "Poles apart? An exploration of single-sex and mixed-sex educational environments in Australia and England," Educ. Stud., vol. 26, no. 4, pp. 409-422, 2000.

[17] H. Luyten and R. De Jong, "Parallel classes: Differences and similarities teacher effects and school effects in secondary schools," Sch. Eff. Sch. Improv., vol. 9, no. 4, pp. 437-473, 2017.

[18] T. E. Scruggs, M. a Mastropieri, and K. a McDuffie, "Co-teaching in inclusive classrooms: A metasynthesis of qualitative research," Except. Child., vol. 73, no. 4, pp. 392-416, 2007.

[19] Q. Hang and K. Rabren, "An examination of coteaching," Remedial Spec. Educ., vol. 30, no. 5, pp. 259268, 2009.

[20] M. W. Kamens, J. P. Susko, and J. S. Elliott, "Evaluation and supervision of co-teaching: A study of administrator practices in New Jersey," Natl. Assoc. Second. Sch. Princ. NASSP Bull., vol. 97, no. 2, pp. 166-190, Jun. 2013.

[21] N. Bacharach and S. Cloud, "Co-Teaching In Higher Education," J. Coll. Teach. Learn., vol. 4, no. 10, pp. 1926, 2007. 